\title{
The Eggs of Gobius minutus, pictus and microps.
}

\author{
By \\ Marie V. Lebour, D.Sc. \\ Naturalist at the Plymouth Laboratory.
}

With 3 plates.

THE eggs of Gobius minutus and Gobius microps are already known, Petersen $(1892,1917)$ having distinguished between them and figured them. Apparently the only mention of those of Gobius pictus is by Holt and Byrne (1901) who give the size of the eggs as about $0.80^{3} \mathrm{~mm}$. high by $0.65 \mathrm{~mm}$. broad. Gobius minutus and pictus often occur together in the Sound and at the mouth of the Cattewater, but pictus is chiefly to be found near coarse sandy bottoms such as one gets near Duke Rock and New Grounds. Gobius microps occurs usually higher up the rivers, but the eggs and young are to be found occasionally in the Sound in the same localities as minutus and pictus.

Shells with eggs on them are commonly dredged in the Sound, those between Plymouth and the Breakwater are usually minuius, but pictus eggs are dredged from New Grounds and microps sometimes in the Cattewater.

In order to distinguish the eggs of these three species, and especially to obtain the eggs of $G$. pictus, adults of all three species were isolated in separate tanks with shells on the bottom on which the fish laid their eggs. The adults of minutus were from the Cattewater, those of pictus from New Grounds, and microps from Chelson Meadow, which opens into the Laira and where the water varies much in salinity, from almost fresh to ordinary sea-water strength. G. minutus and pictus were put into the tanks into ordinary running sea-water, straight from the vessel in which they were brought in from the dredge. G. microps which were caught in Chelson Meadow at the time when the water was almost fresh were put into a laboratory tank filled with fresh water and sea-water allowed to run in very slowly. In this way the fish were gradually accustomed to the ordinary sea-water of the laboratory and it was a week before this salinity was reached. Experiments wer made in keeping the Gobius microps in fresh-water, but these died ; showing that a certain salinity is necessary. 
It was very difficult to rear the young when once they were hatched. When the eggs were very near hatching they were put in small aërated aquaria standing in running water. In these they were hatched and some of the young were left in the original aquarium wbilst others were transferred to various glass vessels either aërated or not. Only two of the young survived, both $G$. microps. One of these died aged two months, the other is still alive, aged seven months, and is $20 \mathrm{~mm}$. long. Those that lived were reared in a glass jar of three pints capacity containing sea-water, not aërated but containing a small stone with some green Ulva growing on it, twelve fish were placed in this jar directly they were hatched, and ten died in a few days. The remaining two at first ate Ulva spores, then larval Copepods, chiefly harpacticid nauplii which were in the water and from fine plankton which was given in small quantities. Afterwards they ate small adult Copepods. The only one remaining is now eating small Amphipods and tresh water Isopods. The water in the jar has never been changed, only a little fresh water added to make up for evaporation. In selecting the stone with Ulva, care was taken to have no burrowing worms such as Polydora as these eat the young fish. It is very interesting to watch the way the Polydora will encircle a fish with its long tentacles and place it in its mouth. Also there must not be too many Harpacticids, as these also eat the fish. One or two may be allowed to remain so that nauplii may hatch out for food for the little fish.

\section{Gobius minutus (Plate I).}

On April 1st, 1918, a batch of eggs of $G$. minutus was laid in the tank by the isolated specimens. These exactly correspond to several brought in from the Sound and were laid on a valve of the oyster Ostraea edulis. Petersen remarks that both $G$. minutus and $G$. microps prefer the shells of Mya arenaria although Cardium and Mytilus are present. At Roscoff, Guitel (1892) in his delightful account of the breeding habits of $G$. minutus gives Tapes and Cardium as the shells commonly used. Those from th? Sound were on Cardium echinatum, Cardium norvegicum and Mya truncata at various dates from March to July. After the first batch several more were laid in the tank. The illustrations are from some dredged in the Sound which were evidently just laid, as many were in the one-celled stage, other stages from two-cells to a many-celled stage being seen the same day, and these correspond well with those laid in the tank. A drawing was made of an egg every day until they hatched in fourteen days. On the second day the blastoderm is well differentiated, on the third day the embryo and neural groove can be distinctly seen; eyes show on the fourth day, slight pigment on the body on the fifth; eyepigment begins on the sixth day and gradually increases as the body pigment becomes more concentrated. On the thirteenth day the pupils 

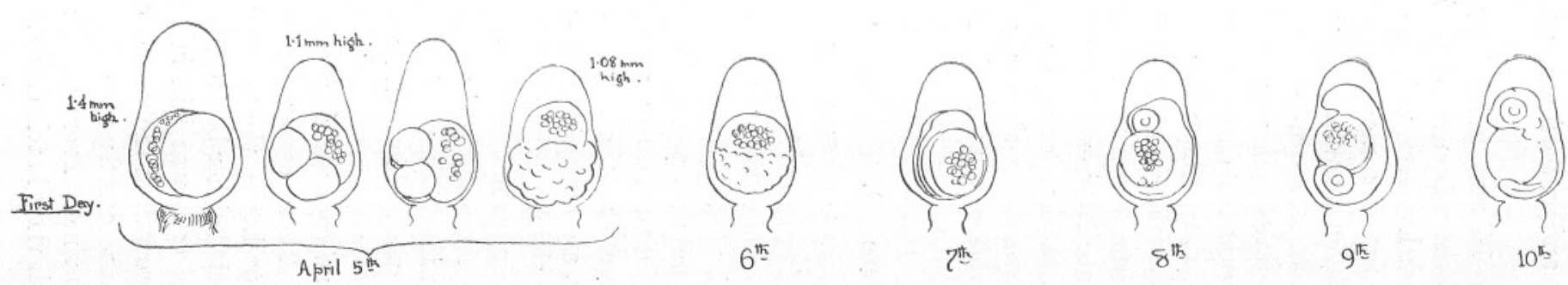

క్

$11^{12}$
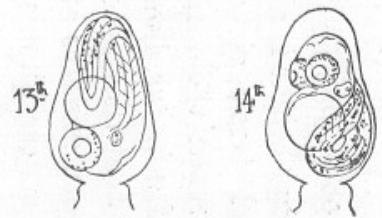

$15^{5}$

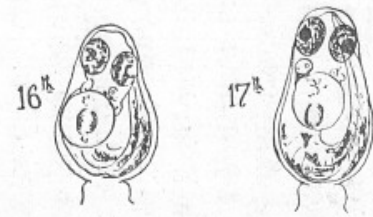

$M$

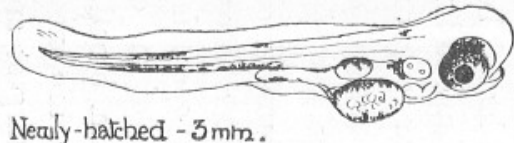


are black and the blood corpuscles are red. and on the fourteenth day the littl 3 fish hatches out.

The egg capsule varies from $1.08 \mathrm{~mm}$. to $1.4 \mathrm{~mm}$. in height and about $0.7 \mathrm{~mm}$. to $0.8 \mathrm{~mm}$. broad, $1 \cdot 1-1 \cdot 2 \mathrm{~mm}$. being the usual size, Petersen gives 0.9 to $1 \mathrm{~mm}$. The newly hatched fish has been well described by Petersen (loc. cit. 1917 and 1919) who also figures some stages of the egg (1892). The pigment is black and a bright orange-yellow, arranged in ramifying chromatophores along the body, and the eye is iridescent with yellowish tinges. It measures $3 \mathrm{~mm}$. or a little more when hatched. At $3.5 \mathrm{~mm}$. the yolk sac has gone and the young fish eats small organisms. One kept in an aërated aquarium standing in running water ate several diatoms amongst which were many Asterionella japonica, Skeletonema costatum and nine cells of Chatoceros curvisetus given it with some very fine plankton. Another of the same size ate a Copepod nauplius. Unfortunately none of these young fish lived, the longest time that any of them lasted being fourteen days. Other specimens ate Copepod larvæ and Annelid larvæ, and one contained a Peridinium, probably P. ovatum. and two cells of Thalassiosira gravida.

\section{Gobius microps (Plate II).}

A number of Gobius microps were obtained from Chelson Meadow, as described above, and on May 9th, a batch of eggs was found on a valve of Pecten opercularis. These had probably been laid about three days. The height of the eggs was from $0.85 \mathrm{~mm}$. to $1 \mathrm{~mm}$. high and $0.65 \mathrm{~mm}$. to $0.7 \mathrm{~mm}$. broad. The usual height is about $0.8 \mathrm{~mm}$. to $0.9 \mathrm{~mm}$., those of $1 \mathrm{~mm}$. are exceptional. Petersen gives the height as $0.7 \mathrm{~mm}$. to $0.9 \mathrm{~mm}$. The largest specimens reach the same height as the smallest eggs of G. minutus; the eggs of minutus, however, are always narrower in proportion to the height, so that they are more slender in build than those of microps. The eggs of both minutus and microps laid in the tanks agree very well with Petersen's descriptions and figures. Unfortunately this first lot of eggs was eaten by something in the tank, possibly a stickleback which had been brought in with the gobies, and which was finally removed to another tank.

On May 15th, a batch of eggs of Gobius microps was found in Chelson Meadow laid on a piece of rusty old tin. These eggs measured $0 \cdot 80$ $0.86 \mathrm{~mm}$. in height and were nearly ready to hatch, the yellow pigment being particularly brilliant. All the young died either before or just after hatching. On May 20th, another batch of eggs was laid in the tank, evidently just laid when found, as many were still in the one-celled stage and one of these was watched between 10.15 a.m. and 2 p.m., going through the 2, 4, 8 and many-celled stages in that time. From this batch the figures were drawn, one egg every day until they hatched out. On the 
Gobius microps, laid in tank May $20^{\star} 1919$, on valve of Pecten opercularis, drazun every day till hatched.
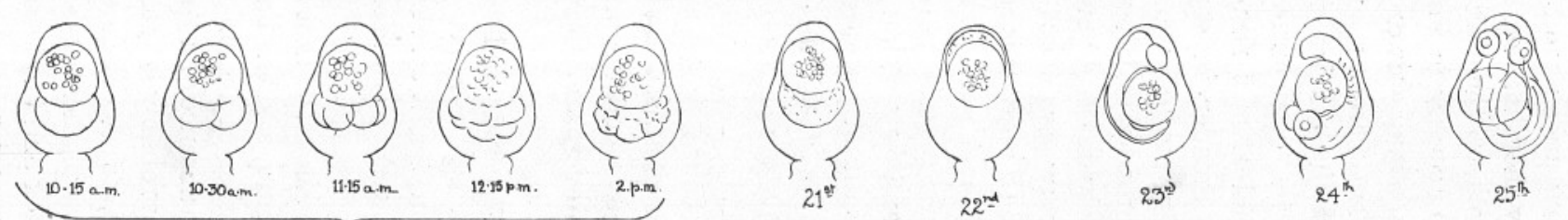

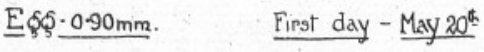
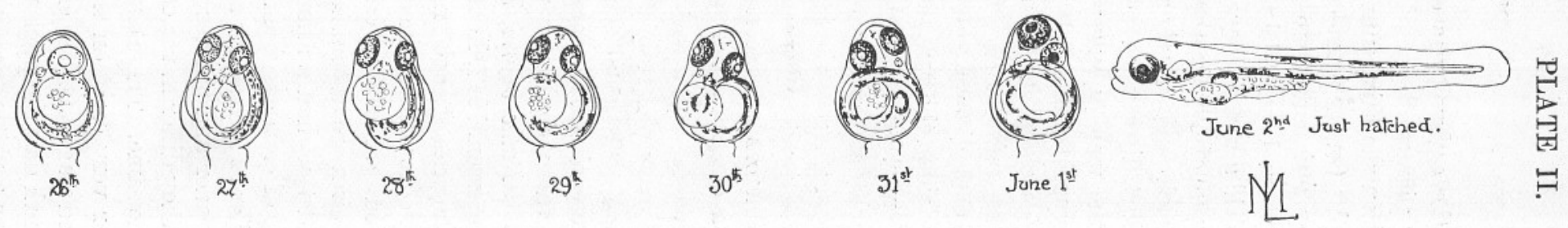
fourth day the embryo was clearly seen with head and eyes, on the seventh day pigment began, gradually concentrating, the eyes getting darker, until on the thirteenth day the pupils were black and the b'ood corpuscles red. On the fourteenth day they hatched at $3 \mathrm{~mm}$., or rather less. Many experiments were made to keep them alive, only two living more than sixteen days. The method of rearing is described above.

On May 27th, a batch of eggs of G. microps was dredged in the Cattewater on a valve of Cardium norvegicum. These eggs measured $0.8 \mathrm{~mm}$.$0.9 \mathrm{~mm}$. in height and exactly agreed with those laid in the tank.

We can thus distinguish between the eggs of Gobius minutus and microps by the usually larger size and always more slender build of minutus, microps being smaller, and broader in comparison with its height. An occasional large microps egg may be the same height as an unusually small minutus egg, but is broader and has a squatter build. There is very little difference in the newly hatched young, those hatching from the eggs laid in the tanks both measuring about $3 \mathrm{~mm}$.; G. minutus may reach $3.5 \mathrm{~mm}$. before hatching and $G$. microps is sometimes less than $3 \mathrm{~mm}$. The chromatophores on the dorsal part of the body are both large in microps, whereas the front one in minutus is usually small. The unpaired chromatophore beneath the auditory region in microps is very pronounced, whereas it is inconspicuous although present in minutus, and microps has a chromatophore behind the eye which is not present in minutus.

\section{Gobius pictus (Plate III).}

Having differentiated the eggs of Gobius minutus and microps it is easy to distinguish those of pictus, which are smaller than microps and are very much more like Ruthensparri, but the latter are slightly shouldered at the top (see Petersen, 1917, Lebour, 1919).

Some Gobius pictus dredged from New Grounds were isolated in a tank and a batch of eggs was obtained in a shell of Patella vulgata on April 26th. These measured $0.75 \mathrm{~mm}$. to $0.8 \mathrm{~mm}$. in height and in shape resembled those of microps more than minutus, as they were broad compared with the height and thus had a stumpy appearance. A distinct feature was the separation of each egg from its neighbour, so that the eggs were not so close together as in minutus and microps, and the base for attachment was much broader and shorter than either of these. From the eggs of Ruthensparri they differ in the complete absence of a "shoulder," the size being much the same. These eggs were probably laid the day before they were found, or very early on that day, as the blastoderm had reached the many-celled stage. On the eighth day pigment appeared on the body, on the thirteenth day the pupil was black and the blood corpuscles were red, and on the fourteenth day the young fish hatched. Unfortunately 
Gobius pictus. Eşs laid in tank April 2601919. in shell of Patella valgata, drazun every day till hatched.

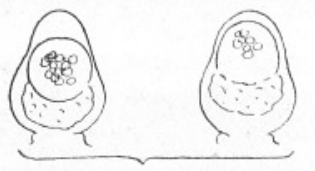

April $28^{\text {th }}-0.8 \mathrm{~mm}$ high
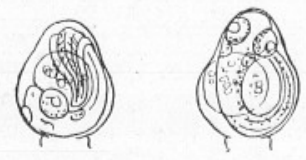

May $33^{2}$

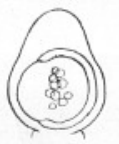

Aproil $22^{\text {th }}$

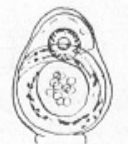

May $5^{\text {th }}$

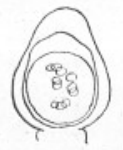

April $28^{\text {th }}$

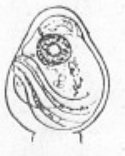

May $6^{\text {th }}$

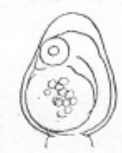

April $29^{\text {th }}$

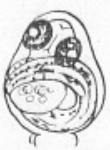

May $7^{\text {t5 }}$

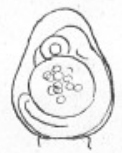

April $30^{\frac{15}{5}}$

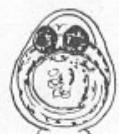

May $8^{\text {th }}$

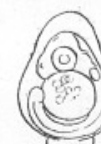

May $1^{\text {th }}$

May 2:-

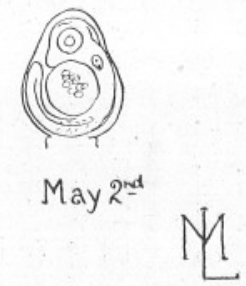

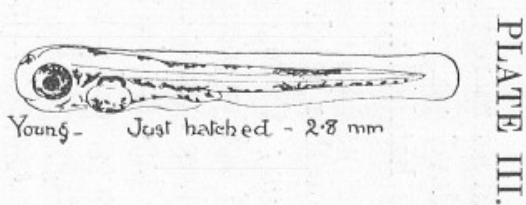


none of these lived for more than a few days. The pigment is not nearly so intense in the developing fish inside the egg as it is in G. Ruthensparri and the young is hatched at $2 \cdot 7-3 \mathrm{~mm}$., G. Ruthensparri being hatched at $2 \cdot 2-2 \cdot 5 \mathrm{~mm}$.

On May 13th, another batch of eggs was found in the tank in a valve of Cardium echinatum; these eggs measured $7 \cdot 2 \mathrm{~mm}$. in height. Other batches of eggs of Gobius pictus were dredged from New Grounds on the sandy bottom; these measured from $0.75 \mathrm{~mm}$. to $0.8 \mathrm{~mm}$. in he: ght.

The eggs of all three species take fourteen days to hatch, and it is seen that a'though the eggs of Gobius minutus, microps and pictus are very much alike, yet they can be distinguished from one another and from those of $G$. Ruthensparri which closely resemble those of pictus.

\section{LITERATURE.}

1892. Guitel, F. "Observations sur les Mœurs de Gobius minutus." Arch. Zool., Paris, 2 S., X.

1901. Holt, E. W. L., and Byrne, L. W. "The British and Irish Gobies." Rep. on the Sea and Inland Fisheries of Ireland. Scientific Investigations.

1919. Lebour, M.V. "The Young of the Gobiidæ from the neighbourhood of Plymouth.” Journ. Mar. Biol. Assoc., XII, 1, 1919.

1892. Petersen, C. G. J. "On the Eggs and Breeding of our Gobiidæ." Rep. Danish Biol. Stat. 1891-92, II.

1917. _ _ "On the Development of our Common Gobies (Gobius) from the Egg to the Adult Stages, etc." Ibid. XXIV, 1916.

1919. — " Vore Kutlinger (Gobiidæ) fra Egget til voksen Fisk." Ibid. XXVI, 1919. 